\title{
O podstawowych stanowiskach w etyce antycznej
}

\author{
Edmund Husserl (1859 - 1938)
}

\section{Wprowadzenie tłumaczki: Wykłady Edmunda Husserla o etyce antycznej}

Prezentowany w przekładzie na język polski wykład Edmunda Husserla pochodzi z tomu Wprowadzenie do etyki [Einleitung in die Ethik], z rozdziału drugiego, zatytułowanego Podstawowe stanowiska etyki antycznej i wstęp do etyki nowożytnej [Grundpositionen der Ethik der Antike und ein Ausblick auf die neuzeitliche Ethik]. Wprowadzenie do etyki wydane jako 38 tom Husserliana w roku 2004 to zbiór wykładów Husserla wygłoszonych we Freiburgu, po raz pierwszy w semestrze letnim 1920 roku, pod takim właśnie zbiorczym tytułem: „Einletung in die Ethik”, a następnie powtórzonych w semestrze letnim 1924 roku - w cyklu wykładów „Grundprobleme der Ethik”.

Henning Peucker (Uniwersytet w Paderborn), który ten złożony w Leuven manuskrypt przygotował do druku, pisze we wprowadzeniu:

\footnotetext{
Wykład charaketryzuje się tym, że krytyczne rozważenie centralnych dla historii etyki poglądów i koncepcji, służy wprowadzeniu w etykę samego Husserla. Wykład ten zatem dokumentuje zarazem zainteresowanie Husserla historią etyki, jak i stan etyki fenomenologicznej na początku dwudziestego wieku (Puecker, w: Husserl 2004, XIII).
}

Jak zatem zauważa Peuckner, wykład Husserla stanowi krytyczną historę etyki Husserl czyta i wykłada podstawowe dzieła i poglądy z obszaru filozofii moralnej i etyki zawsze problemowo, nie stricte historycznie, sytuując prezentowane stanowiska - a tym samym, dosłownie: ich filozoficzne znaczenie, ich doniosłość - w kontekście fenomenologii, jako że ta nie stanowi poglądu, szkoły czy też nawet ruchu $\mathrm{w}$ dziejach historii filozofii, lecz filozofię par excellence, filozofię pierwszą, metodę. Sam dyskurs Husserla jest zatem fenomenologiczny, nieustępujący jakiejkolwiek potocznej narracji historycznej. 
Pierwszej redakcji manuskryptu przygtowywanego do druku dokonali Husserl oraz Ludwig Landgrebe, od roku 1923 ówczesny asystent Husserla we Freiburgu. Ostateczny układ tekstu pochodzi jednak z redakcji Pueckera: Wykłady uporządkowane zostały w paragrafy, a te następnie zebrane $\mathrm{w}$ dziesięciu rozdziałach. W mym przekonaniu motywem przewodnim tych rozdziałów jest obecna w całej spuściźnie Husserla - począwszy od Badań logicznych, poprzez Filozofię jako naukę ścisła, Erste Philosophie, aż po Kryzys nauk europejskich - jego krytyka greckiej sofistyki i jej nowożytnych reinkarnacji, np. siedemnastowiecznego naturalizmu, dziewiętnastowiecznego pozytwizmu oraz współczesnego Husserlowi scjentyzmu.

Wprowadzenie do etyki uwzględnić bowiem należy, chcąc wykazać zasadniczą spójność Husserlowskiej wykładni celu filozofii/filozofowania oraz kierującego jego badaniami ideału poznania bezzałożeniowego - jako stale obecnych w jego wykładach i rozprawach. Naglącą koniecznością pozostaje podjęcie gruntownego przebadania pism Husserla $\mathrm{z}$ uwzględnieniem następujących zagadnień: (i) nawiązanie Husserla do greckiego ideału prote philosophia, (ii) terminologiczne nawiązanie do platońskiej idei jako przedmiotu poznania a priori, (iii) związki fenomenologicznej epoche z sokratejskim ideałem bezzałożeniowości, (iv) krytyka pozytywizmu, sceptycyzmu oraz wynikającego z nich relatywizmu jako współczesnych form sofistyki (Bogaczyk-Vormayr 2011, 3).

Jest warte podkreślenia, że cały tom wykładów rozpoczyna się zdefiniowaniem etyki jako uniwersalnej sztuki słusznego postępowania (universale Kunstlehre von den richtigen handlungsleitenden Zwecken). W tym paragrafie pierwszego rozdziału Husserl nie powołuje się na Arystotelesa - tj. nie cytuje go -, ale formułując wypowiedź filozoficzną (a nie historyczną) prezentuje stanowisko, które historyk etyki nazwać musi arystotelejskim, wyrażającym koncepcje celowości, przydatności i zasadności ludzkiego działania. Husserlowa Kunstlehre najbliższa jest - co ciekawe, uzględniwszy właśnie pojemność obu tych kategorii greckiej techne.

Pierwszy rozdział, jak przystało, jest wykładem metodologicznym i - czego także powinniśmy się po Husserlu spodziewać - propozycją fenomenologicznego ujęcia etyki. Jednakże dla czytelnika wyłącznie polskich przekładów prac Husserla (zatem, de facto, najważniejszej, ale niewielkiej części jego spuścizny) zaskakujące 
może być ujęcie głęboko dowartościowujące filozofię praktyczną właśnie w postulacie oderwania od niej filozofii teoretycznej (sic!). Mowa tu o piątym paragrafie pierwszego rodziału: Konieczność rozdzielenia badań czysto teoretycznych i badań zorientowanych praktycznie. Idea czystej logiki a etyka [Die Notwendigkeit einer Scheidung der rein theoretischen von der praktisch orientierten Forschung. Die Idee einer reinen Logik und Ethik]. Tymczasem znając rozprawy etyczne Husserla, zarówno powstałe na użytek dydaktyczny, jak np. Grundprobleme der Ethik z roku 1908, aczkolwiek mające wysoce spekulatywny charakter, jak chociażby części II-IV $\mathrm{z}$ tomu Vorlesungen über Ethik und Wertlehre [Wykłady z etyki i teorii wartości] z lat 1908-1914, jak i te powstałe w celu spopularyzowania jego stanowiska na gruncie akademickim, jak np. tzw. Kaizo-Artikel z lat 1923-24, nie sposób dziwić się i tutaj wyrażonemu przez niego stanowisku. Husserl nie jest bowiem zdania, że znaczenie etyki jako dyscypliny filozoficznej uzasadni się, wpisując ją w logikę czy nawet aksjologię (formale Axiologie). Etyka mianowicie (etyka kompetentnie uprawiana to jest sedno wywodu Husserla) jest dyscypliną samodzielną, a nadawanie jej niejako splendoru logiki albo rzekomej nauki szczegółowej, chociażby „znaturalizowanej psychologii”, świadczy o braku dyspozycji badawczych. ${ }^{1}$

Interesujące - i z całą pewnością wymagające krytycznej analizy - jest zaproponowane przez Husserla ujęcie hedonizmu (rozdziały 4 - 5), mianowicie jako etycznego egoizmu, sceptycyzmu oraz dogmatyzmu (sic!), wyrażające m.in. stosunek Husserla wobec koncepcji Maxa Stirnera, ale, co wydaje mi się najważniejsze, przedstawione $\mathrm{w}$ kontynuacji do rozdziału trzeciego, traktującego obszernie o Hobbsowskiej filozofii państwa z jej podstawową zasadą ochrony własnego bytu. Z

\footnotetext{
1 To przekonanie Husserla warto dzisiaj przywoływać. Współcześnie, gdy myśl podporządkowana została wymogom i zadaniom zawodowym, gdy de facto w akademii marginalizuje się myślenie, wyklucza namysł jako wymykający się parametrom według których obliczana jest efektywność, przeliczana następnie w systemie punktowym, stanowisko Husserla przypomina nam, czym jest kondycja filozofa - jego wszechstronność i samodzielność zarazem. Tak relacjonuje wpływ tej właśnie postawy Husserla na jego studentów i kolegów Helmuth Plessner: „Dwa pokolenia oczarowane zostały takimi cechami pracy Husserla, jak wyrzeczenie się systematycznej spójności na rzecz gromadzenia wielości tematów, wola pracy, otwartość na świat, wypracowana wstrzemięźliwość, poprzestawanie na małym, cierpliwość dla fragmentarycznych ujęć i rezygnacja z wielkości. Taka była historia wejścia filozofii w świat współczesnej pracy naukowej, historia przezwyciężenia historyzowania, relatywizowania, zerwania z pisaniem książek o książkach, po to, by dotrzeć do rzeczy samej. Otwarta na doświadczenie współczesność uzyskała wreszcie swoją filozofię rozumianą jako jedna $\mathrm{z}$ wielu fachowych dziedzin, jako praca badawcza o otwartym horyzoncie." (Plessner 1987, 9).
} 
kolei rozdział szósty poświęcony jest zagadnieniu motywacji i pomimo jego skrótowości zasługuje na miano samodzielnej rozprawy w obrębie Wprowadzenia do etyki, rozprawy prezentującej stanowisko Husserla znane doskonale z wielu jego pism, a w mej opinii najciekawiej wyłożone nie np. w Badaniach Logicznych czy w rozprawach, którym polscy badacze fenomenologii zwykli przyznawać podobną „doniosłość naukowości”, lecz w jego wykładach właśnie - z etyki czy z psychologii (np. cykl „Intentionale Psychologie”). Chodzi tu mianowicie Husserlowi o jego krytykę naturalizmu psychologicznego jako nieuzasadnionej i zaprzeczającej arbitralności dyscyplin humanistycznych próby „imitowania dyskursu nauk szczegółowych", jak to wyraził w samym Wprowadzeniu do etyki (widersinnige Naturalisierung; Imitation der Naturwissenschaften; cf. § 26). Wykłady ostatnie poświęcił Husserl obszernej analizie filozofii moralnej Hume'a oraz Kantowskiej etyce czystego rozumu, jednak i w tych ostatnich rozdziałach postacią przewodnią myśli Husserla pozostaje Sokrates. Przykładowo, zdaniem Husserla, w Kantowskiej krytyce hedonizmu powtarza się argumentacja Sokratesa, a sama jego postawa traktowana jest $\mathrm{w}$ etyce oraz filozofii moralnej jako paradygmatyczna (Husserl: „stawiana za wzór”) przez kolejnych filozofów, w tym również Kanta.

Po owych dziesięciu rozdziałach, stanowiących zapis regularnego wykładu Husserla, następuje obszerny wykład (Exkurs) zatytułowany Natura i duch. Nauki szczegółowe i normatywne. Nauki przyrodnicze i humanistyczne [Natur und Geist. Sachwissenschaften und normative Wissenschaften. Naturwissenschaften und Geisteswissenschaften] oraz w sumie 22 krótkie teksty nazwane dodatkami. Wykład „Natura i duch” był wygłoszony w ramach cyklu „Wprowadzenie do etyki”, nie został jednak przez Husserla i Landgrebego włączony do manuskryptu - już na etapie przygotowywania wykładów do publikacji. Ponadto manuskrypt złożony w Leuven posiada na marginesie liczne notatki Landgrebego, na podstawie których ustalono, iż niektóre fragmenty z Natur und Geist ${ }^{2}$ Landgrebe włączył do pracy Erfahrung und Urteil, także przez niego zredagowanej (Puecker, XXXVI). Wszystkie dodatki zebrane na końcu książki stanowiły notatki samego Husserla, sporządzane przez niego w ramach przygotowywania wykładów, głównie jeszcze w roku 1920, a niektóre spośród nich stanowią wręcz zapiski z marginesu tychże wykładów lub dołączone

\footnotetext{
2 Tej rozprawy nie należy mylić z wykładem „Natur und Geist“ z semestru wiosennego 1919, wydanego w Husserliana Materialien B. IV, 2002.
} 
zostały przez samego Husserla do manuskryptu wykładów w celu ich późniejszego wkomponowania w ciągły tekst tego cyklu, do czego niestety nigdy nie doszło (ibid.).

W tychże wykładach po raz kolejny wyczuwamy, jak silne napięcie dostrzegał Husserl w problematyce sporu na linii empiryzm - racjonalizm. To ten problem miał popchnąć go w latach 20-tych zarówno do pracy nad Erste Philosophie, jak i nad wykładami z etyki (cf. Puecker, XXII-XXIII). W moim przekonaniu trzy prace Husserla, po dzień dzisiejszy znane w języku polskim jedynie fragmentarycznie, stanowią jego najważniejszą wykładnię filozofii fenomenologicznej jako sięgającej do źródłowości greckiej, do metody Sokratesa-Platona. Są to Erste Philosophie, Einleitung in die Ethik i tzw. Kaizo-Artikel. Te ostatnie stanowią poniekąd skrótową oraz, jak już wspomniano, popularyzującą ówczesne stanowisko Husserla część jego projektu odnowy filozofii i kultury duchowej - w nawiązaniu do greckiej tradycji teoriopoznawczej i etycznej. Każdy z tych pięciu artykułów traktuje o odnowie (Erneuerung) $^{3}$ i tym samym wraz z Erste Philosophie i Wprowadzeniem do etyki tworzą materiał do zrozumienia filozoficznego rozwoju Husserla od Filozofii jako nauki ścisłej po oba Kryzysy. Samo Wprowadzenie natomiast stanowi w mym przekonaniu prawdziwy pomost między tymi trzema - dość jeszcze wczesnym i najpóźniejszymi - kluczowymi dziełami Husserla.

\section{Edmund Husserl: 0 podstawowych stanowiskach w etyce antycznej}

\subsection{Sofistyczna skepsis u początków historii etyki}

Niezadowalający rozwój etyki jako jednej z podstawowych nauk filozoficznych powoduje, że musi ona niejako ustawicznie domagać się uznania swej roli, walczyć o własne swe znaczenie i doniosłość swej problematyki. Wygląda to tak, jakby etyka nadal jeszcze, czy też dopiero teraz, musiała wywalczyć sobie własne miejsce, tzn. uzasadnić swe podstawowe przesłanki oraz metody. A czyni to wobec sceptycyzmu,

\footnotetext{
3 Trzy artykuły zatytułowane kolejno: Erneuerung. Ihr Problem und ihre Methode; Die Methode der Wesenforschung; Erneuerung als individualethisches Problem ukazały się w japońskim czasopiśmie „Kaizo“ w latach 1923-24, czwarty i piąty z „Kaizo-artykułów“ pt. Erneuerung und Wissenschaft. Formale Typen der Kultur in der Menschheitsentwicklung z 1923 r. nie zostały tam ostatecznie opublikowane (Nenon, Sepp 1989, X-XVII).
} 
który w różnych swych formach i kolejnych przebraniach zaprzecza wszystkiemu, co należy do istoty zagadnień etycznych.

W niniejszym wykładzie podejmiemy się zatem historyczno-krytycznego przedstawienia tego problemu. Będą Państwo, jak sądzę, w tej dobrej - w sensie dydaktycznym - sytuacji, że zajmiemy się najpierw rozważeniem początków etyki, umieszczając pierwszych przedstawicieli tej dyscypliny niejako na przedstopniach doniosłego zamiaru, jakim był rozwój idei na gruncie etyki (ethische Ideenentwicklung), co zdaje się być bliskie Państwa sytuacji - sytuacji początkujących filozofów. Owi pierwsi filozofowie będą także tym łatwiej zrozumiali dla Państwa jako stojących na początku swych studiów -, gdyż byli oni jeszcze odlegli od ustanowienia konkretnego przedmiotu oglądu (Anschauungsmaterial), na podstawie którego krytyka filozoficzna może odsłonić własne swe systematycznie przeprowadzone wnioski.

W samym centrum duchowego rozwoju ludzkości, w toku formowania się obyczajów, praw, nauki, religii i języka - jako tego, w czym odbijają się wszystkie nasze twory duchowe - rozwija się także życie etyczne człowieka. Podstawowe wyobrażenia oraz normy etyczne wyrosły w sposób naturalny, powiemy: naiwny, stając się składowymi całej tradycji, w której wzrasta każde nowe pokolenie, traktujące ją jako jego naturalne, zastane środowisko duchowe. Rzecz jasna: to, co etyczne $\mathrm{w}$ tradycyjnym sensie, $\mathrm{w}$ pierwotnym kształcie normalizowania naszego życia społecznego, wyprzedza etykę jako naukę. Etyczność jako coś obiektywnego wiąże każdy poszczególny przypadek, gdyż w swym przekroczeniu przypadkowości jest tym, co dane bezspornie. Choćbyśmy nie zdawali sobie z tego sprawy, to właśnie tak dzieje się już od pokoleń, że etyka ma za zadanie przemyśleć zasadność nakazów wyrażanych poprzez liczne reguły, stawiając je pod znakiem zapytania, czyniąc je przedmiotem teoretycznego namysłu.

Tak było i u greków. Im też zawdzięczamy pierwszą formę europejskiej kultury naukowej - aż do czasu sofistów, przywódców tzw. greckiego Oświecenia, czyli aż do V w. p.n.e. Sofistów poprzedzili pierwsi greccy filozofowie. Okres przedsofistyczny oznaczał początek idei nauki (rzecz jasna, w jej jeszcze zalążkowej postaci, pełnej niejasności i sprzeczności). Sofistyka skierowała się nie tylko przeciwko tak rozumianej filozofii w jej specyfice, lecz przeciw samej idei nauki, przeciw samej możliwości obiektywnego i obowiązującego poznania. Wkrótce 
jednak uświadomiwszy sobie paralelizm pomiędzy wymogiem prawdy obiektywnej oraz etycznym, czyli praktycznym wymogiem prawa, sofiści poczęli w swych tezach krytykować także roszczenia praktycznych norm etycznych.

Dotychczas filozofia nie poświęcała uwagi praktyczno-etycznej sferze życia. Zatem paradoksalnie początek historii etyki wiąże się z etyczną skepsis. Więcej nawet: nie mamy tu do czynienia z sytuacją, którą znamy z nauk przyrodniczych i z metafizyki, gdzie na początku występuje pewna dogmatyczna forma nauki, przeciw której sofistyka kieruje swą krytykę, lecz z sytuacją, w której to krytyka wobec zastanych i tradycyjnie wiodących idei i norm etycznych staje się początkiem oraz siłą zmieniającej je nauki, czyli etyki.

Jak powiedziano, sofiści odrzucali możliwość czy też sens prawdy obiektywnej, a zatem poznanie prawdy. Prawdziwe jest - powiada Protagoras - to, co wydaje mi się prawdą. Jemu też przypisuje się następujące słowa: „Dla każdego to jest dobre, co jemu samemu takim się zdaje." Tym samym w sferze wartości, a nade wszystko w sferze etyki zostaje zrelatywizowany oraz następnie zniesiony obiektywny sens tego, co dobre.

Jednak to dopiero tzw. młodsza sofistyka $\mathrm{z}$ niespożytą energią $\mathrm{i}$ konsekwencją doprowadziła do sytuacji ekstremalnej. Stara sofistyka w jej walce $z$ irracjonalizmem wynikającym z historycznej niemal władzy pewnych koncepcji, a nade wszystko w krytyce politycznej, dokonała początkowo rozróżnienia, które w żadnym wypadku nie wprowadziło do etyki tego negatywistycznego, wszystko podważającego charakteru. Dokonała po prostu rozróżnienia pomiędzy fúsij i nÒmoj. Jest to rozróżnienie między tym, co obowiązuje ludzi z przyczyn naturalnych, co uznają za naturalne, a tym, co stanowi prawo pozytywne, które zostaje ustanowione przez władzę lub które stanowi prawo tradycyjne, czyli przyjęte zwyczaje. To konwencjonalne prawo pozytywne, jak uważali sofiści, nie jest żadnym autentycznym (wahres und echtes) prawem i nie wynikają z niego istotnie wiążące obowiązki, które przypisywano tzw. prawu naturalnemu - jako temu, które swe źródło ma w samej naturze człowieka. Przed naturą, jak wiadomo, ugnie się każdy rozumny człowiek.

Idea „sankcji naturalnej”, pewnego rodzaju redukcja prawa i rozumności do „tego, co naturalne” - co odbija się w językowej koincydencji słów „naturalny” oraz „rozumny” - była jeszcze wystarczająco niejasna, także na skutek dwuznaczności słowa „naturalny”, aby zachęcać do przyjęcia postawy sceptycznej. Sceptycyzm zatem 
nie tracił czasu i pomysł ten miał swe dalsze, jak najbardziej znaczące, konsekwencje, odziałując na refleksję etyczną kolejnych kilku tysięcy lat.

Pozostańmy jednak przy sofistyce. W swym tak pochopnie przyjętym radykalizmie wskazała ona wpierw (i miało to pewną wartość na ówczesnym etapie rozwoju etyki), że w dziedzinie moralności nie występuje żadne autentycznie uzasadnialne, powszechne obowiązywanie (Allgemeingültigkeit), że nie istnieje nic nakazanego „z natury”, nic takiego jak dobro samo w sobie. Można to zaobserwować, jak uważano, w różnicach co do ludzkich poglądów dotyczących prawa i obowiązków, które, po pierwsze, odmienne są u różnych narodów, a po drugie, zmieniają się wraz z upływem czasu.

Jeśli odwołać się do tego, że najwięksi myśliciele i poeci, a także, podążając za nimi, wszyscy rozumni ludzie cenią sobie jak najwyżej sprawiedliwość jako kalÒn, sofista odpowie: „Ależ naturalnie! Kto żyje w zgodzie z prawem i moralnością, kto nikomu nie wyrządza krzywdy, nie zabiera, co nie jego, kto jest wobec innych uprzejmy i miły, ten wygrywa tym samym szacunek i poważanie, i tak robi karierę. A jeżeli będzie postępował odwrotnie, zostanie znienawidzony i ukarany. A zatem, nasza pochwała moralnego postępowaniu naszych bliźnich, ma swe prawdziwe źródło w korzyści, jaką widzimy dla siebie samych w moralnym zachowaniu innych. I jeśli ktoś sam ugina się wobec obowiązujących zasad moralnych, czyni tak, ponieważ w zgodzie z nimi przysługuje mu pewna korzyść, którą ma nadzieję uzyskać, korzyść wynikająca z systemu kar i nagród. Ostatecznie bowiem istnieje tylko jeden prawdziwy motyw w całym procesie wartościowania i działania - jest nim korzyść własna. Jeśli niesprawiedliwość przynosi nam taką samą korzyść, możemy zdecydować się na nią przewidując pewne jej konsekwencje i w ten sposób uniknąć pewnych złych skutków - osiągamy to mianowicie dzięki samemu wrażeniu (Schein) sprawiedliwości. Bylibyśmy głupcami, nie korzystając z tego."

Odnajdziemy w tym stanowisku i inne jeszcze, podobne motywy, które w późniejszych czasach powracały do nas w przeróżnych postaciach - przykładowo, że przepisy prawa oraz sprawiedliwość są wynalazkami słabeuszy, chroniącymi ich przed ludźmi silnymi; albo też, że prawa stanowią kompromis pomiędzy wspólnymi wszystkim ludziom żądzą posiadania i używania wszelkich dóbr a strachem przed przewidywaną ze strony innych nienawiścią. W każdym razie ten, kto jest wystarczająco silny i wpływowy, by nie musiał lękać się innych, nie robi sobie nic z 
takiego kompromisu. Sofiści powiedzieliby: taki człowiek zrywa krępujące go więzy, depcze sprawiedliwość i takie właśnie jest jego naturalne prawo! Natura, podobno, chce, aby rządził ten, kto jest solidny, władczy, silniejszy.

\subsection{Reakcja Sokratesa przeciw sofistyce jako początek nauki o etyce}

Etyka jako nauka powstała z reakcji przeciw przedstawionym powyżej poglądom. Impuls określający cały późniejszy rozwój etyki pochodzi od Sokratesa, chociaż on sam nie był filozofem teoretycznym, tzw. człowiekiem nauki, lecz reformatorem w sferze praktyki. Jego oddziaływanie, jego wpływ dał w ogóle początek epoce nowej filozofii, opartej na radykalnych podstawach (Begründungen), co umożliwiło epokę nauki rygorystycznej (strenge Wissenschaft). Początkowo Sokrates zagłębił się i doskonalił $\mathrm{w}$ wewnętrznym wysiłku kierowania się ku prawdzie, co oznaczało odpowiedzialność wobec samego siebie, a co stało się centralną siłą jego osobowości i jego oddziaływania. Sokrates jako pierwszy ćwiczył się, jeszcze w odniesieniu do konkretnych spraw i tylko w wymiarze praktycznym, w metodzie oglądu istoty (Methode der Wesenschau), próbował wypracować to, co istotowe (Wesenhaftes), uchwycić prawdziwe znaczenie pojęć. Z tej metody, jako najdoskonalsza forma jej rozwoju, wyłoniła się platońska metoda poznania apriorycznego oraz platońska reforma nauki, bez której nie zaistniałaby nigdy nauka we właściwym sensie nauki ścisłej (exakte Wissenschaft).

Dialog sokratejski (jak wiadomo, życie Sokratesa - i jego oddziaływanie toczyło się $\mathrm{w}$ dysputach) kieruje ku uzyskaniu pełnego poznania istoty (vollkommene Wesenseinsicht), tj. prowadzi do duchowego oglądu (geistiges Erschauen) tego, co tylko w czystym wysiłku poznania jawi sią jako rozstrzygająca jasność, intuitywne wypełnienie pierwotnie niejasnych intencji (Denkintentionen), zmierzania do „wypatrzenia” istoty wartości (Erschauen des Wesens praktischer Werte), wglądu w to, co stanowi o ich autentyczności i prawdziwości (was ihr Echtes und Wahres ausmacht). Sokrates rozpoznał, że istnieje coś takiego, jak niepowątpiewalne poznanie dane w oglądzie (erschauende Einsicht), prawdziwe i autentyczne (Wahre und Echte) w jego własnej istocie, i że nie przytrafia się ono człowiekowi niczym boski dar, lecz jest dla każdego osiągalne w metodycznie przeprowadzonym procesie myślowym. Wejrzenie (Einsicht) jest czym innym niż samym, choćby nawet 
inteligentnym i pomysłowym, mniemaniem. Gdyż wobec wielości mniemań i wielości zakładanych w nich wartości istnieje jedno, autentyczne i prawdziwe dobro, które ujmowane jest we wglądzie (im geistigen Schauen) i jako takie stanowi coś absolutnie pewnego, bezwzględnie obowiązującego i będącego (Geltendes und Seiendes), na czym należy oprzeć własne życie.

Sokrates nie uprawiał tzw. filozofii systematycznej i dlatego tradycyjnie przywoływane wypowiedzi Sokratesa nie są teoremami wyrażonymi z pojęciową dokładnością oraz z odpowiadającym jej naukowym uzasadnieniem. Można je natomiast różnie interpretować, ujmując je jako dość proste lub podkreślając w nich to, co naprawdę głębokie. Jeśli się je rozważa z perspektywy filozofii platońskiej, stanowiącej autentyczną realizację (Auswirkung) sokratejskiego impulsu, rozumie się, jak głęboka, nawet jeśli nie rozwinięta jeszcze do postaci koncepcji, jak bezgraniczna była mądrość (Weisheit) słów Sokratesa. Dotyczy to jego powszechnie znanych poglądów, jak tych, że „dzielności można się nauczyć”, że „słuszne poznanie jest źródłem słusznego działania” a „wszelki błąd moralny ma swe źródło w braku wiedzy”, że „każdy człowiek ze swej natury dąży do tego, co uważa za słuszne i nikt z własnej woli nie opowiada się za brakiem dobra".

Nawet w tych jego poglądach, które krytyka Sokratesa nazywa hedonizmem, tkwi wielka mądrość. Stwierdzenie, że dobro oraz to, co stanowi dla człowieka prawdziwą eudaimonię przynosić ma człowiekowi jakąś korzyść, brzmi dla nas z początku obco. Jeśli jednak przeanalizujemy podobne wypowiedzi Sokratesa $\mathrm{z}$ należytą uwagą, dojdziemy szybko do zrozumienia ich głębokiej treści: Kto kieruje się frònesij, wglądem rozumu (Vernunfteinsicht), ten wybiera prawdziwe dobro, a zarazem doświadcza spełnienia, tzn. szczęścia. Prawdziwe szczęście nie przychodzi do człowieka z zewnątrz, nie spada na nas niczym jakiś dar prosto z nieba. Źródło wszelkiego prawdziwego szczęścia jest w nas samych, w naszym rozumie, w pracy nad sobą (Selbsttätigkeit), a stąd następnie w wynikającym z nich skierowaniu się ku dobru - także w praktycznym wymiarze naszego życia.

Sokrates jest jak najdalszy od pogardy dla ludzkich dążeń i potrzeb, tak samo obce jest mu postulowanie etyki eudajmonistycznej w znaczeniu późniejszej etyki hedonistycznej. Etykę Sokratesa należy rozumieć jako etykę doskonałości (Vollkommenheitsethik). Jego zdaniem, tak jak tzw. prawdziwa cnota stanowi wewnętrznie zharmonizowany stan duszy $w$ jej wszystkich właściwościach i 
pragnieniach, a zatem duchową doskonałość, tak i zdrowie ciała jest pewną doskonałością. Zdaniem Sokratesa nic innego jak sam rozum nie może powodować, że życie konsekwentnie skierowane ku temu, co dobre, jest życiem, w którym osiągamy spełnienie.

Nie należy za bardzo kierować się pełnym sprzeczności i ujmującym Sokratesowi jego portretem przekazanym nam przez Ksenofonta. Uczynił on $\mathrm{z}$ Sokratesa naiwnego głosiciela prostej myśli, iż doprawdy nie ma dla człowieka nic piękniejszego, niż być dobrym i mieć wielu przyjaciół, którzy dzięki naszej dobroci także na pewno staną się lepsi. Z całą pewnością etyka Sokratesa jest etyką w dopiero kształtującej się, zalążkowej formie; nie została rozwinięta przez niego do postaci nauki, a pewne ważne motywy tej etyki zostały nawet wprowadzone bez ich systematycznie przeprowadzonego opracowania. Jednak nauka, która potrafiłaby ująć owe wartości i poglądy w ich ostateczną logiczną formułę, mogła i musiała nadejść dopiero po Sokratesie.

\section{References:}

Bogaczyk-Vormayr, Małgorzata 2011. Autoreferat rozprawy doktorskiej. http://filozof.amu.edu.pl/wp-content/uploads/downloads/2012/10/M.BogaczykVormayr Autoreferat-rozprawy-doktorskiej.pdf (dostęp: 10.08.2016).

Husserl, Edmund. 2004. Einleitung in die Ethik. Vorlesungen Sommersemester 1920/1924. Dordrecht-Boston-London: Kluwer Academic Publishers.

Nenon, Thomas \& Sepp, Rainer. 1989. Einleitung der Herausgegeber. W: Husserl, Edmund. Aufsätze und Vorträge (1922-1937), Husserliana B. 27. Dordrecht Boston - London: Kluwer Academic Publishers.

Puecker, Henning. 2004, Einleitung des Herausgebers, w: Husserl, E. 2004. Einleitung in die Ethik. Vorlesungen Sommersemester 1920/1924. Dordrecht - Boston London: Kluwer Academic Publishers.

Plessner, Helmuth. 1987. Husserl w Getyndze. Tł. A. Załus. Studia Filozoficzne 1 (254): 5-17. 
Edmund Husserl (1859 - 1938)

\section{About the Fundamental Views in Ancient Ethics}

Abstract: Translated text comes from Edmund Husserl's course "Einleitung in die Ethik" ["Introduction into Ethics"] from the spring semester 1920, repeated and extended in the spring semester 1924, each time in Freiburg. Husserl presents Socrates as a reformer of philosophy and philosophical practice - in his criticism of sophistic, skepsis and empiricism. As Bogaczyk-Vormayr emphasizes in her introduction, Husserl does not evoke any historical paradigm, he does not want to simply said - be a historian of philosophy; on the contrary, he presents his view of ethics, which we should call a phenomenological one. That means he offers a critical history of philosophy - his analyses are focused on philosophical ideas and only their philosophical potential is what matters to him.

Keywords: Socrates, Socratic dialogue, praxis, sophistic, truth, phenomenology, eudaimonia, happiness, wisdom

Ethics in Progress (ISSN 2084-9257). Vol. 7 (2016). No. 2, Art. \#8, pp. 104-115.

Creative Commons BY-SA 3.0

Doi: 10.14746/eip.2016.2.7 